\title{
An Assessment of Rural Solid Waste Management System in Aguata Local Government Area, Anambra State, Nigeria
}

\author{
Igwe P.U. and Evan E. \\ Department of Environment Management, Chukwuemeka Odumegwu Ojukwu University, Uli. \\ Nigeria.
}

Received: 10 Jan. 2020 / Accepted 10 March 2020 / Publication date: 30 March 2020

\begin{abstract}
Wastes are inevitable products of human activities in both cities and rural settings across the globe. Solid waste management is increasingly becoming a problem in rural settings of developing democracies. This paper has been done to assess rural solid waste management system in Aguata Local Government Area Anambra State Nigeria. The research methods are quantitative approach using structured questionnaire to collect data from respondents and setting of traps to collect vectors of diseases and rodents at dumpsites in rural communities of the study area. A multi-stage sampling technique was used in selecting 6 towns out of the 14 towns of the study area, zoned into: north, central and south. A simple random technique was made use of in choosing 3 villages from each of the 6 towns, translating into 18 villages that were sampled. Then 10 respondents were sampled from each of the 18 villages giving a total of 180 respondents from households selected through a systematic sampling technique. Product Moment Pearson Correlation Coefficient statistical analysis was used which showed that there was a positive correlation between the improper rural solid waste management system and public health in a relationship: $\mathrm{r}=0.842, \mathrm{p}<0.05(5 \%)$, with the significance level $=0.035$. Poor handling of rural solid wastes constitutes both environmental and health risks in Aguata Local Government Area. Government, individuals, and community-based organizations should see waste management as a collective enterprise to avert imminent epidemics.
\end{abstract}

Keywords: Aguata, Assessment, Rural solid wastes, Waste management system

\section{Introduction}

Wastes arise inevitably from human activities in homes, markets, churches, industries, offices, hotels/restaurants, schools, farms, tourist areas and social gatherings. Waste generation is as old as creation itself. At the dawn of creation and for many past centuries, wastes never constituted a major problem as it is in this $21^{\text {st }}$ century merely because they were not much and there were available sinks such as vast areas of uninhabited lands for them. More so, they were less complex in composition. In the view of UNEP (2005), solid wastes were not a major problem in the past because almost everything was re-used, recycled and whatever remained was taken care of by nature. Today, however, due to rise in human numbers, technological advancement, change in consumption styles and abandonment of nomadic life which led to the creation of permanent communities accompanying recent global development, many nations including Nigeria are facing environmental and public health risks occasioned by solid wastes.

In the past, solid waste management was given a low priority in most municipalities, conference rooms and government offices responsible for public health and safety (Pitchel, 2005), until in the $19^{\text {th }}$ century when the idea of collecting and disposal of wastes in a systematic manner became part of the way to improve public health and safety (Vlachos, 2000). In Nigeria, solid waste management is concentrated in cities such as Abuja, Lagos, Kano, Enugu, Calabar and Port Harcourt. The rural communities are ignored by the authorities responsible for solid waste management as the inhabitants do not have a voice and are not properly integrated into governance.

Waste and solid wastes have been defined by a number of researchers. In the opinion of Oluwaleye (2012), waste is something that has no value, useless and wants to be discarded by owner.

Corresponding Author: Igwe P.U., Barley Res Department of Environment Management, Chukwuemeka Odumegwu Ojukwu University, Uli. Nigeria.

E-mail: greenscenario2100@gmail.com 
Ogwueleka (2003) stated that a number of 600 people in 15 Nigeria towns defined waste as follows: unwanted materials ( $8 \%$ ); useless object (20\%); garbage (22\%); rubbish $(7 \%)$; dirt $(15 \%)$ and refuse (28\%). In the US, wastes include objects that the lay audience commonly calls garbage, refuse and trash (Davis and Masten, 2004). Solid wastes are any unwanted or non-useful solid substances generated in human population which comprise of refuse from houses, non-hazardous solid wastes from industrial, commercial and institutional establishments, market wastes, yard wastes and sweepings (Kaseva and Mbuligwe, 2003). Waste is a man-made thing that has no purpose, or is not able to perform with respect to its purpose (Prongracz, 2003). According to him, waste is bound with life.

Handling of solid waste materials is problematic both in developed and developing democracies as the quantum of these wastes is ever increasing every year. UNH (2009) reported that the total amount of municipal solid wastes generated globally reached 2.02 billion tons in 2006, representing $7 \%$ annual increase from 2003. This is mainly because of rise in human numbers and high consumption rates accompanying improved economic situation. By 2025, it is expected to rise to 19 billion tons annually (Yoshizawa et al., 2004). No doubt, there is an emerging concern about large quantities of solid wastes being generated both in urban and rural settings across the globe. In the light of this, the concept of solid waste management became a key focus of sustainable development policies and practices that are resource-conserving following set standards that can be met in the long term.

Solid waste management has been referred to as involving collection, transport, treatment and disposal of solid wastes including after care of disposal sites (Gbekor, 2003). Techobanglous et al. (1993) opined that solid waste management is that discipline associated with the control of generation, storage, collection, transfer and transportation, processing and disposal of solid wastes. Similarly, Ogwueleka (2003) stated that solid waste management is that area associated with the control of generation, storage, collection, transportation, processing and disposal of solid wastes in a manner that is in accordance with best principles of public health, economics, engineering, conservation, aesthetics and other environmental conditions.

Rural solid waste management is the collection, transport, processing recycling or disposal of solid waste materials, usually ones produced by human activities, in an effort to reduce their effects on human health or local aesthetics or amenities (WHO, 2006). In its view, the central objective of rural solid waste management is to protect human health and improve quality of life among people living in rural areas. Additionally, it stated that majority of the rural areas do not keep records on solid waste generation, origin, characteristics and this constitutes a huge challenge for local governments due to its constant increase and this leads to vector-borne diseases such as diarrhea, malaria, polio, dengue, cholera, typhoid and schistosomiasis. However, a number of rural solid waste management practices are in place in communities across Nigeria. For example, Izuagbara and Umoh (2005) identified some indigenous solid waste management practices among the Ngwa kingdom in Abia State which included: burying, burning, composting and mulching, among others. These practices are a form of taking back the wastes for purposes of management in line with the assertion of Cole et al., (2019) that everyone who sells electrical electronic waste should do a sort of take-back of the wastes.

In Nigeria, solid wastes constitute risks both in urban and rural settings. The risks arising from improper solid waste management are increasing and also being compounded by a vicious circle of poverty, population explosion, decreasing standard of living, low level of environmental education and awareness, rapid and haphazard industrialization, inevitable increase in waste generation and bad governance. Although large investments go into meeting the challenges of effective solid waste management in Nigeria in recent times, there is little evidence that such efforts have their expected impacts (Medina, 2002). The risks of inadequate solid waste management are very evident in rural areas where there is high level of poverty, low environmental education and awareness, ignorance and indiscriminate disposal of rural solid wastes. This is the current situation in Aguata Local Government Area. In the light of the foregoing, this study, therefore, assesses the current rural solid waste management system in the study area so as to proffer solutions. 


\section{Theoretical/Conceptual Framework: Sustainable Waste Management}

This research is rooted on the concept of sustainable waste management so as to achieve the optimum priority of solid waste management system which is to ensure human health and safety. Sustainable waste management is an integral part of sustainable development (the Brundtland Commission's Approach) defined as development which seeks to meet the needs of the present without compromising the ability of future generations to meet their own needs (WCED, 1987). Thus, in line with the objectives of sustainable development, sustainable waste management can be regarded as an approach to waste management that, in addition to protecting human health and the environment, ensures that scarce resources of the earth are conserved for both present and future generations of humanity. It therefore, becomes important to minimize natural resources extraction and consumption by recycling waste materials, and conduct waste management efficiently to curtail the environmental impacts of waste disposal and protect ecosystem services for both current and future generations (MAR, 2005). Rural solid wastes can be sustainably managed. Reducing the amounts of wastes we produce, in line with waste management hierarchy, is the best way to achieve sustainable waste management (Girling, 2005) in rural settings. Where waste generation is unavoidable, a sustainable approach to management is to reuse and recycle products to prevent them from getting into the waste stream. If waste prevention/reduction, reuse and recycle become economically impossible, waste is processed to recover their intrinsic value such as energy.

\section{The Study Area}

Aguata Local Government Area is located between latitudes $5^{\circ} 08^{\prime} \mathrm{N}, 5^{\circ} 05^{\prime} \mathrm{N}$ and longitudes $7^{\circ} 01^{\prime} \mathrm{E}, 7^{\circ} 15^{\prime} \mathrm{E}$ in Anambra State, Nigeria (Figure 1). It is bounded by Anaocha Local Government Area in the north, Imo State in the south, Orumba North Local Government Area in the east and Nnewi South Local Government Area in the west. It is made up of 14 component towns, namely: Achina, Aguluezechukwu, Akpo, Amesi, Ekwulobia, Ezinifite, Igboukwu, Ikenga, Isuofia, Nkpologwu, Oraeri, Uga,Umuchu and Umuonaas shown in Figure 1.

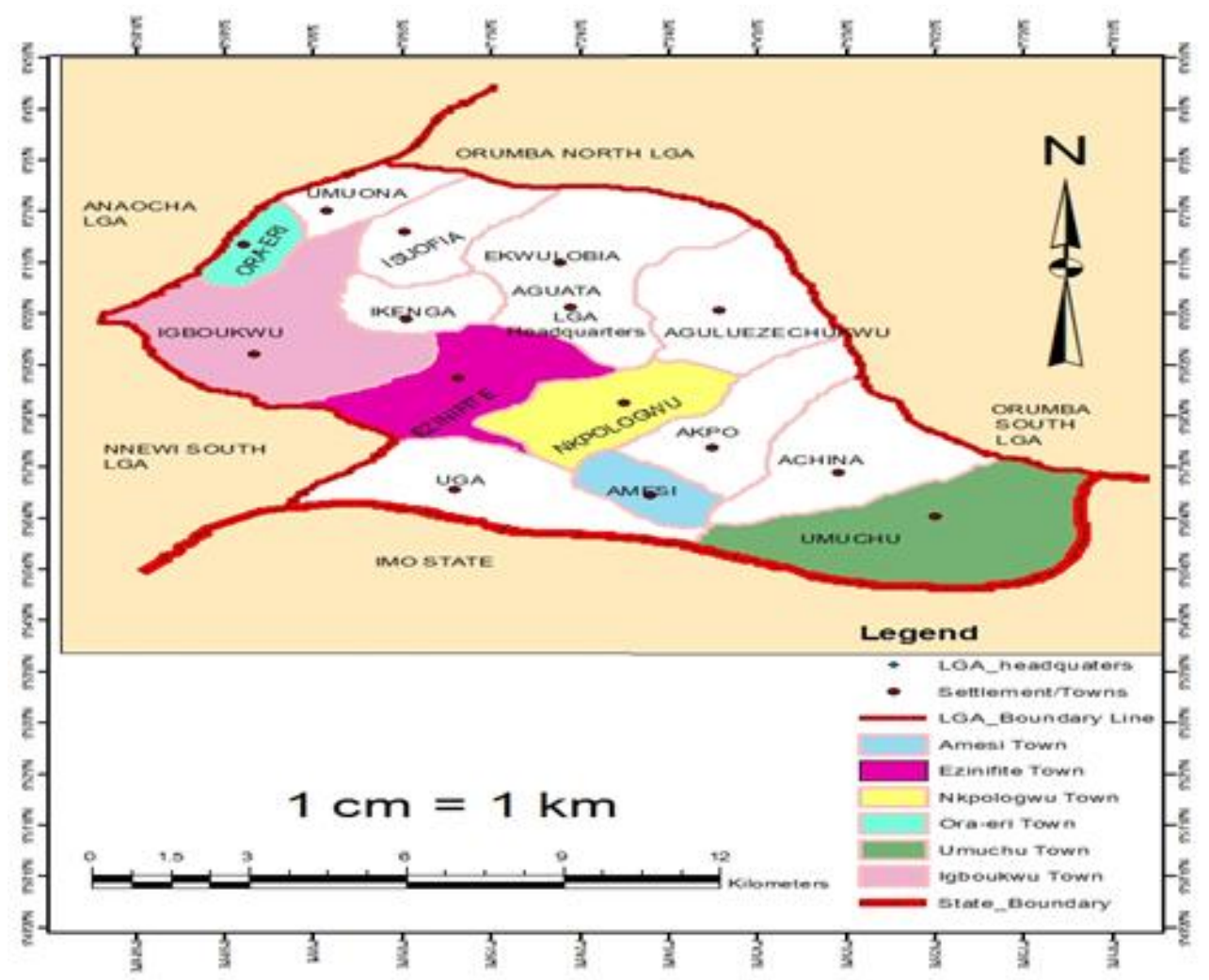

Fig. 1: Map of Aguata Local Government Area showing the sample towns in colours.

Source: Office of the Surveyor General of the Federation (OSGOF) Abuja, 2018 
Geologically, the study area is underlain by the Precambrian basement complex of shales interbeded with sandstones and limestones. The geology of the study area is characterized by its metamorphic and sedimentary rocks from the earlier ones of the lower cretaceous. These rocks are simply sandstones, calcareous shale and shelly limestone in thin bands. Geomorphologically, the area has very little rolling topography undulating with gentle valleys. There are some very tall trees pointing out from the valleys. Gullies created by mainly running water and some human factors are found in every town of the study area. The soils are derived from sandstones parent materials of the Mesozoic sedimentary rocks. The soils are also pale brown loamy alluvial soils, characterized by fresh water swamp forests, dip brown red soils derived from sandstone deposits. USDA (1999) classified the soils of the area into two: ferraltic soil (formed as a result of chemical weathering, rich in iron, aluminum and low silica content) and hydromorphic soils (caused by underlying impervious shales from shales which are influenced by seasonal water logging).

Hitherto, the study area which was known for its luxuriant rainforest vegetation as it lies within the rainforest zone of Nigeria has now been reduced to derived savanna vegetation of scrub/shrub/bushes as a result of a number of both physical (natural) and anthropogenic (human) factors. In the view of UNH (2009), the tropical rainforest of the study area has been degraded over years as a result of increase in human population and human activities such as deforestation, lumbering, bush fries, overgrazing and land utilization for development. By 2006, the population of the study area was 369,972, with 187,262 males and 182710 females (NPC, 2006). With the approved 3.2\% annual population growth rate by NPC, the population of the study area has been projected to 476,523 in 2015 . No doubt the upward trend in human numbers in the study area translates into a rise in generation of rural solid wastes and indeed the environmental and health risks posed by such wastes. A number of economic activities in the study area that account for the large quantum of wastes includes: widespread cropping activities, small-scale industries, trading, carpentry, tailoring and motor/motorcycle repairs, among others. Economic trees such as mango (Maginifera indica), paw-paw (Carica papaya), orange (Citrus sinensis), palm tree (Elasis guineensis), guava (Psidium guajave), almond (Amygdalus coommunis dulcis), and pear (Pyruscommunis) are mostly found in the area.

\section{Materials and Methods}

\section{Sources of Data}

Primary and secondary sources were made use of in this research. Primary data came mainly from respondents' answers to questionnaires and vectors of diseases caught at dumpsites. Primary data were generated from six towns out of the fourteen component towns of the study area as shown in Figure 1 which were selected in such a way that all parts of the study area were covered. Secondary information from the Department of Planning, Aguata Local Government Area was also made use of. Other sources of secondary data include textbooks, journals, newspapers, bulletins, conference/seminar papers and technical reports that were found to be very relevant to the study.

\section{Sampling Techniques and Procedure of Data Analysis}

A multi-stage sampling technique was used in selecting the sample for the study. The 14 towns of the study area shown in Figure 1 were zoned into three: north, central, and south. This forms the first stage (primary) sampling units. Then 2 towns were chosen at random from each of the zones and this constitutes the second stage (secondary) sampling units. This was followed by the selection of 3 villages at random from each of the 6 sampled towns for the study. This translates into 18 villages that were sampled, 6 villages from each of the zones. Ten respondents were chosen from each of the 18 villages which give a total of 180 respondents that make up the sample size. Systematic sampling technique was used in selecting the sample households. Out of every 3 buildings along one road within each of the 18 selected villages, 1 building was sampled. Tables, percentages and Product Moment Pearson Correlation statistical analysis were used in analyzing data generated in the course of the study. 


\section{Methods of Data Collection and Analysis}

The methods used in generating data and information for the studies are observation, questionnaire, interview and setting of traps/nets at dumpsites. The researchers made a critical observation of how rural solid wastes have been indiscriminately deposited by roadsides, inside drains and gullies. Disposal of rural solid wastes at forests, wetlands, watersheds and markets was also observed. Dumpsites were seen as homes for some vectors of diseases and rodents. Photos were taken to capture the physical state of the environment at the rural solid waste dumpsites. A structured questionnaire comprising of 24 open-and close-ended questions was used in collecting data and information from 180 respondents on issues such as methods of rural solid waste disposal, problems of rural solid waste management and adaptation to the problem of rural solid waste management. Target population for the questionnaire survey was both men and women from 20 years and above in order to ensure reliability of information. One of the researchers, Evan, E. administered the questionnaire by hand to the respondents and also collected back the same way. Some of the respondents, 24 from households and 2 from Aguata Local Government Planning Department were interviewed by one of the researchers, Igwe, P.U. so as to gain more knowledge about the study. Sticky traps, water traps and sweep nets were set at 8 rural solid waste dumpsites across the 6 sampled towns by Evan, E. to catch some vectors of diseases and rodents. She also weighed the wastes to find their characters and quantities using a weighing balance. Tables and percentages were extensively used in the presentation of data got from the field survey. Product Moment Pearson Correlation Coefficient statistical analysis was used to know the relationship existing between poor handling of rural solid waste and public health. The correlation test in given in a relationship:

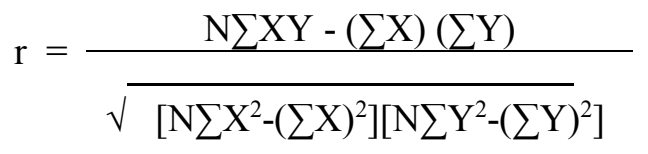

where, $\sum X Y=$ Multiplying each paired score of $X$ and to obtain column $X Y$

$\mathrm{X}^{2}=$ Square of each score in column $\mathrm{X}$

$\mathrm{Y}^{2}=$ Square of each score in column $\mathrm{Y}$

$\sum X=$ Sum of all scores in column $X$

$\sum \mathrm{Y}=$ Sum of all scores in column $\mathrm{Y}$

$\mathrm{r}=$ Substituting the values in the formula

\section{Results and Discussion}

In Aguata Local Government Area, wastes are described using so many terms, including doti, afifa, ngwongwo and ahiha. All these portray wastes as something that has no value and as such should be thrown away. The Aguata people place rural solid wastes in two categories: degradable and non-degradable. In the sampled locations, rural solid wastes were composed of so many items which include garbage, metals/tins/cans, glasses, bottles, rags, nylon, cell battery, syringes and needles, papers, plastics, empty sachets of pure water and leaves. This composition makes rural solid wastes to share common characteristics as municipal solid wastes. In homes, degradable rural solid wastes are burnt or used as manure in farms or baiting for animals, while the non-degradable ones are indiscriminately disposed off at market dumpsites, gullies, roadsides, wetlands/watersheds, drains and forests as depicted in Plates1(a-c). Mixed (co-mingled) rural solid wastes are found mainly in markets, small-and medium-scale industries, hotels and social gatherings. Improper disposal of rural solid wastes arises mainly because the Government of Anambra State and that of Aguata Local Government Area are not discharging their responsibility of ensuring a safe environment to the citizenry through the collection and proper disposal of these rural solid wastes. 


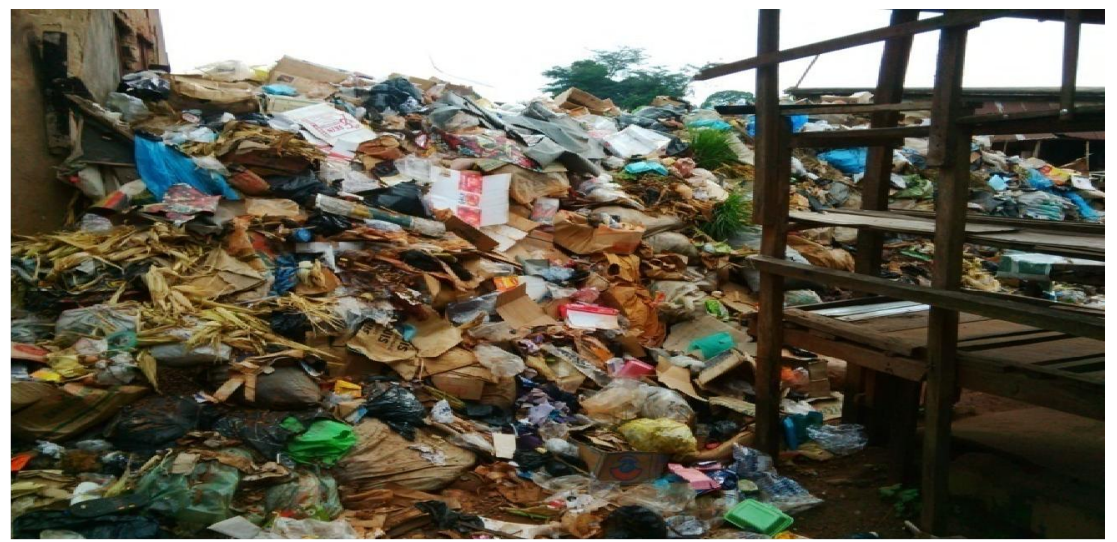

Plate 1a: A rural solid waste dumpsite at Afor Market, Ubaha, Amesi Town

Source: Researchers' field-work, 2018

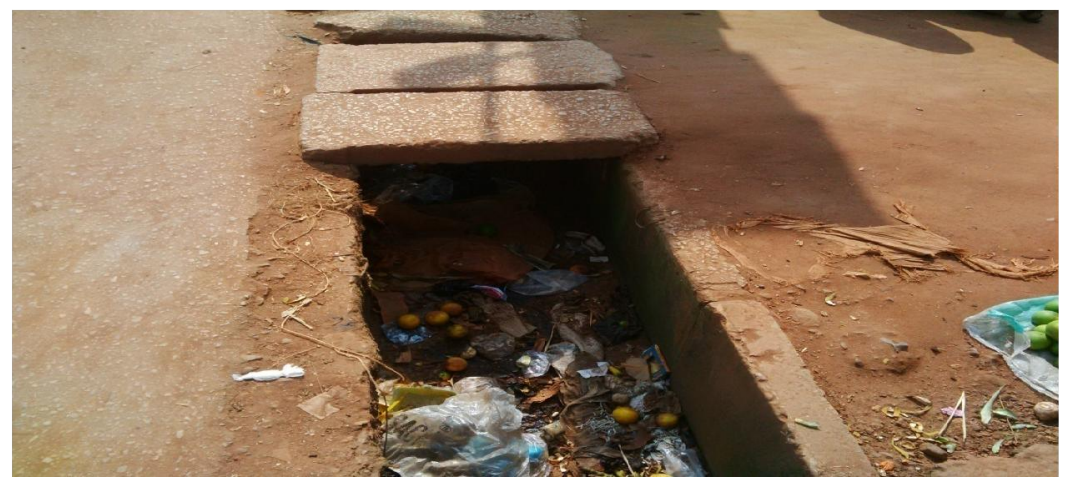

Plate 1b: Indiscriminate disposal of rural solid waste inside a drain close to Premier Secondary School, Obinabo village, Nkpologwu Town

Source: Researchers' field-work, 2018.

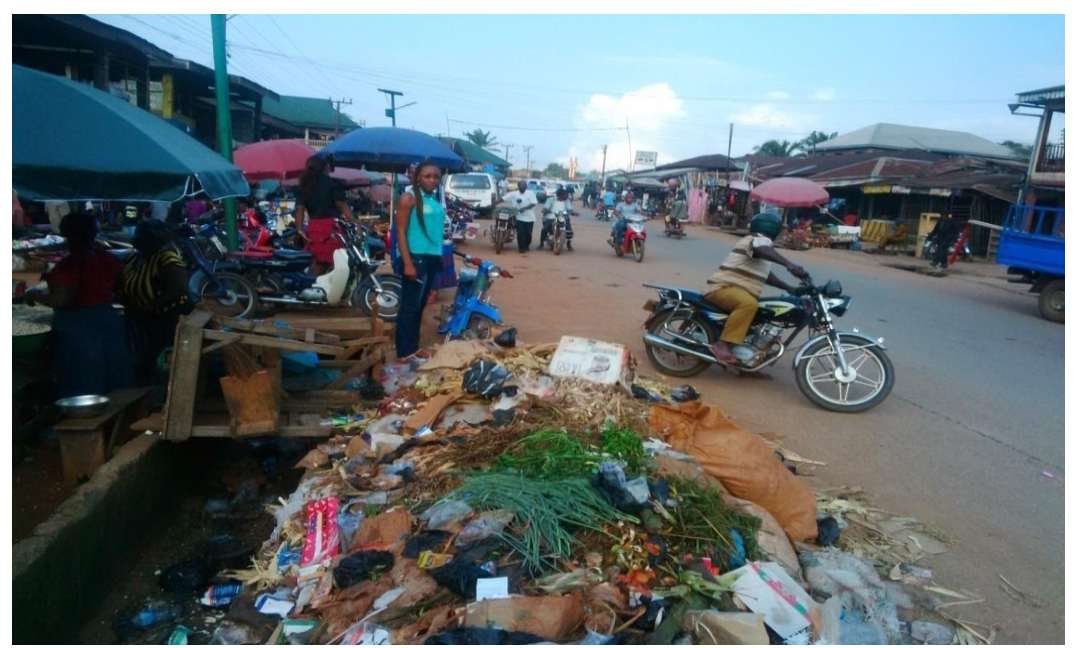

Plate 1c: Indiscriminate dumping of rural solid wastes by a roadside at Nkwo Market, Igbo-ukwu Town

Source: Researchers' field-work, 2018

Rural solid wastes generated in the study area are rarely collected regularly. Irregularity tantamounts to environmental injustice as noted by Igwe (2012 a,b). Due to irregular collection of rural solid wastes in the study area, $48.33 \%$ of the respondents dump their wastes inside forests and farms, while $27.78 \%$ do so at gullies and wetlands. Those who throw away their wastes by roadsides and drains constitute $22.22 \%$, whereas $16.67 \%$ use abandoned buildings as dumpsites. No wastes are dumped inside streams/rivers by rural dwellers because of their traditional belief of possible grave repercussions from the gods of the water bodies (Table 1). The implication is that there is lack of rural 
solid wastes collection/disposal system in the area and it goes a long way to affirm the inadequacy of the wastes management system and lack of capacity by the authorities to discharge their statutory responsibilities.

Table 1: Respondents' opinion on the places where residents dump their wastes

\begin{tabular}{lcccccccc}
\multicolumn{1}{c}{ Towns } & $\begin{array}{c}\text { Roadsides/ } \\
\text { Drains }\end{array}$ & $\begin{array}{c}\text { Forest/ } \\
\text { Farms }\end{array}$ & $\begin{array}{c}\text { Streams/ } \\
\text { Rivers }\end{array}$ & $\begin{array}{c}\text { Gullies/ } \\
\text { Wetlands }\end{array}$ & $\begin{array}{c}\text { Abandoned } \\
\text { buildings }\end{array}$ & Others & Total & $\%$ \\
\hline Ezinifite & 5 & 15 & - & 10 & - & - & 30 & 16.67 \\
Nkpologwu & 7 & 17 & - & 6 & - & - & 30 & 16.67 \\
Igbo-ukwu & 10 & 15 & - & 5 & - & - & 30 & 16.67 \\
Ora-eri & 2 & 12 & - & 14 & 2 & - & 30 & 16.67 \\
Amesi & 6 & 15 & - & 8 & 1 & - & 30 & 16.67 \\
Umuchu & 10 & 13 & - & 7 & - & - & 30 & 16.67 \\
Total & 40 & 87 & - & 50 & 3 & - & 180 & 100 \\
\% & 22.22 & 48.33 & - & 27.78 & 16.67 & - & 100 & \\
\hline
\end{tabular}

Source: Researchers' field-work, 2018

Despite the grossly inadequate rural solid waste management system by the authorities in the study area, the rural dwellers have developed a number of indigenous and adaptive solid waste management techniques in nature, including burying, baiting, mulching and scare crows. In homes, management of rural solid wastes starts with segregation of the wastes into degradable and nondegradable categories and then the adaptive measures. Table 2 shows that respondents who practise burning of waste materials constitute $27.22 \%$, while $22.22 \%$ bury them. Other indigenous rural solid wastes management practices in place in the area are reuse (16.11\%) compositing (15.56), animal bedding $(6.11 \%)$, baiting $(5.00 \%)$ mulching/ scale crows $(4.44 \%)$ and recycling $(3.33 \%)$.

Table 2: Respondents' opinion on how solid wastes are being managed

\begin{tabular}{lccccc}
\hline Towns & Burying & Composting & Burning & Re-use & Baiting \\
\hline Ezinifite & 7 & 5 & 8 & 5 & 1 \\
Nkpologwu & 5 & 6 & 8 & 6 & 2 \\
Igbo-ukwu & 10 & 2 & 6 & 3 & 1 \\
Ora-eri & 5 & 6 & 10 & 2 & 2 \\
Amesi & 6 & 5 & 9 & 6 & 2 \\
Umuchu & 7 & 4 & 8 & 7 & 1 \\
Total & 40 & 28 & 49 & 29 & 9 \\
\% & 22.22 & 15.56 & 27.22 & 16.11 & 5.00 \\
\hline
\end{tabular}

Table 2: Continued

\begin{tabular}{lccccc}
\hline Towns & $\begin{array}{c}\text { Mulching/ } \\
\text { Scarecrows }\end{array}$ & Recycling & $\begin{array}{c}\text { Animal } \\
\text { bedding }\end{array}$ & Total & $\%$ \\
\hline Ezinifite & 1 & 1 & 2 & 30 & 16.67 \\
Nkpologwu & 1 & 1 & 1 & 30 & 16.67 \\
Igbo-ukwu & 3 & 2 & 3 & 30 & 16.67 \\
Ora-eri & 1 & - & 4 & 30 & 16.67 \\
Amesi & 1 & - & 1 & 30 & 16.67 \\
Umuchu & 1 & 6 & - & 30 & 16.67 \\
Total & 8 & 3.33 & 6.11 & 180 & 100 \\
\% & 4.44 & & & & \\
\hline
\end{tabular}

Source: Researchers' field-work, 2018

Poor handling of rural solid wastes is a risk to the environment and public health in Aguata Local Government Area. The rural solid waste dumpsites are an eyesore, producing bad order and breeding grounds for vectors of diseases. They also cause land pollution, traffic congestion and flooding as viewed by the respondents. Table 3 depicts that the risks posed by unsafe dumpsites around their neighborhoods are bad odour $(36.67 \%)$ breeding of vectors of disease $(27.22 \%)$, land pollution (17.78), eyesore (10.56\%), traffic congestion (5.00\%) and flooding $(2.78 \%)$. 
Table 3: Respondents' view on the types of risks constituted by the dumpsites

\begin{tabular}{lcccccccc}
\hline Towns & $\begin{array}{c}\text { Breeding of } \\
\text { vectors }\end{array}$ & $\begin{array}{c}\text { Land } \\
\text { Pollution }\end{array}$ & $\begin{array}{c}\text { Bad } \\
\text { Odour }\end{array}$ & $\begin{array}{c}\text { Eye- } \\
\text { sore }\end{array}$ & $\begin{array}{c}\text { Traffic } \\
\text { congestion }\end{array}$ & Flooding & Total & \% \\
\hline Ezinifite & 10 & 6 & 10 & 2 & 2 & - & 30 & 16.67 \\
Nkpologwu & 6 & 5 & 15 & 3 & 1 & - & 30 & 16.67 \\
Igbo-ukwu & 8 & 3 & 10 & 4 & 4 & 1 & 30 & 16.67 \\
Ora-eri & 6 & 5 & 11 & 5 & - & 3 & 30 & 16.67 \\
Amesi & 9 & 7 & 10 & 3 & 1 & - & 30 & 16.67 \\
Umuchu & 10 & 6 & 10 & 2 & 1 & 1 & 30 & 16.67 \\
Total & 49 & 32 & 66 & 19 & 9 & 5 & 180 & 100 \\
\% & 27.22 & 17.78 & 36.67 & 10.56 & 5.00 & 2.78 & 100 & \\
\hline
\end{tabular}

Source: Researchers' field-work, 2018

The sampled dumpsites were observed to harbour and breed a number of vectors of diseases such as insects and rodents. Four insect species and two species of rodents were collected through hand picking, setting of traps and nets. Table 4 shows that water trap method yielded the highest number of insects and rodents $(48.57 \%)$, whereas hand picking $(1.56 \%)$ collected the least.

Table 4: Number of insects and rodents collected using various methods

\begin{tabular}{lccccccc}
\hline Vector Species & $\begin{array}{c}\text { Hand } \\
\text { Picking }\end{array}$ & $\begin{array}{c}\text { Water } \\
\text { trap }\end{array}$ & $\begin{array}{c}\text { Sticky } \\
\text { Trap }\end{array}$ & $\begin{array}{c}\text { Snap } \\
\text { Trap }\end{array}$ & $\begin{array}{c}\text { Sweep } \\
\text { Net }\end{array}$ & Total & $\%$ \\
\hline $\begin{array}{l}\text { Musca domestica(houseflies) } \\
\text { Aedes aegypti, Anopheles gambiae, }\end{array}$ & - & 13 & 15 & - & 92 & 120 & 31.12 \\
$\begin{array}{l}\text { Culexquinquefascias (mosquito) } \\
\text { Biting midges (tiny flies) }\end{array}$ & - & 87 & 26 & - & - & 113 & 29.35 \\
Blattaorientalis(cockroach) & - & 77 & 10 & - & - & 87 & 22.60 \\
Salamanders (lizard-like) & - & 10 & 42 & - & - & 52 & 13.51 \\
Rattus rattus(black rat) & - & - & - & - & - & - & \\
Snails & - & - & 7 & - & - & 7 & 1.82 \\
Total & 6 & - & - & - & - & 6 & 1.56 \\
$\%$ & 6 & 187 & 100 & - & 92 & 385 & 100 \\
\hline
\end{tabular}

Source: Researcher's field-work, 2018

Efforts were made to estimate the quantities of rural solid wastes at dumpsites where traps and nets were set in the sample towns to collect vectors of diseases and rodents so as to apply the Product Moment Pearson Correlation Coefficient statistical analysis. Table 5 shows the quantities of rural solid wastes at dumpsites in each sample town and number of vector species caught.

Table 5: Estimated quantities of rural solid wastes and the frequency of vector species in Aguata

Local Government Area

\begin{tabular}{lcc}
\hline Town & $\begin{array}{c}\text { Estimated quantities of rural } \\
\text { solid wastes in } \mathbf{~ m}^{\mathbf{3}}\end{array}$ & $\begin{array}{c}\text { Total number of vector species caught } \\
\text { at each sample dumpsite }\end{array}$ \\
\hline Ezinifite & 89.1 & 71 \\
Nkpologwu & 80.1 & 61 \\
Igbo-ukwu & 103.8 & 133 \\
Ora-eri & 93.3 & 60 \\
Amesi & 79.5 & 61 \\
Umuchu & 98.6 & 99 \\
\hline
\end{tabular}

Source: Researcher's field-work, 2018

The results in Table 6 depict that the co-efficient of correlation (r) is 0.842 which is above 0.7 based on the decision rule. This shows that there is a positive correlation between rural solid wastes and public health. Therefore, the result for the test of relationship is thus: $r=0.842, p<0.05(5 \%)$, with the significance level $=0.035$. The implication of these observations is that since there is a positive relationship between the quantities of rural solid wastes and the frequency of vectors of diseases which impacts adversely on public health in the study area, one can conclude that poor handling of rural solid wastes constitutes risks to the environment and public health in Aguata Local Government Area. 
Table 6: Results of the Product Moment Pearson's Correlation Coefficient between the poor handling of rural solid wastes and public health

\begin{tabular}{llcc}
\hline & \multicolumn{2}{c}{ Correlations } \\
\cline { 2 - 4 } Sources of Variation & \multicolumn{1}{c}{ Rural Solid Wastes } & Public Health \\
\hline \multirow{3}{*}{ Rural Solid Wastes } & Pearson Correlation (r) & 1 & $0.842^{*}$ \\
& Sig. (2-tailed) & 0.035 \\
& N & 6 & 6 \\
\hline \multirow{2}{*}{ Public Health } & Pearson Correlation (r) & $0.842^{*}$ & 1 \\
& Sig. (2-tailed) & 0.035 & 6 \\
\hline
\end{tabular}

*. Correlation is significant at the 0.05 level (2-tailed).

Source: Statistical Package for Social Sciences Version17 Computer Output, 2018

\section{Conclusion and Recommendations}

Poor handling of rural solid wastes in Aguata Local Government Area constitutes environmental and public health risks, including land pollution, flooding, traffic congestion and breeding grounds for vectors causing diseases such as malaria, dysentery, chlolera, diahorea and lassa fever. The poor rural solid waste management system is evident at the dumpsites, markets, drains, roadsides, gullies, wetlands/watersheds and forests. Through observation of the physical environment of the study area and oral interview of rural dwellers, it was very clear that the Anambra State Waste Management Agency (ASAWMA) which is an environmental institution charged with the responsibility of waste management is not discharging its duties effectively because rural solid wastes are rarely collected. The uncollected wastes will increasingly continue to pose environmental and public health risks, with the potential to trigger outbreak of epidemics, except urgent measures are taken to establish an efficient rural solid waste management system that must be participatory by integrating the interests of all stakeholders, particularly those of the rural dwellers who already have some indigenous rural solid waste management practices.

In the light of the foregoing, the Government of Anambra State in conjunction with that of Aguata Local Government Area ought to provide two waste collection vehicles and also a number of refuse bins at strategic points in every town to help collect the wastes by the ASWAMA for disposal at its designated environment-friendly dumpsites. The Aguata Local Government Area is expected to enact enforceable by-laws against littering of wastes and establish mobile environmental courts for prosecution of offenders. Rural solid waste collection centres and treatment facilities like biodegradation or composting need be established in all communities to reduce the amount of rural solid wastes, generate employment opportunities, help reduce improper disposal of wastes as well as recovery of valuable materials. It is necessary to create environmental awareness and organize educational programmes to teach rural dwellers the environmental and health implications of indiscriminate dumping of rural solid wastes. Through this, rural dwellers should be encouraged to reduce their waste outputs by using the already existing indigenous waste management practices: burying, burning, baiting, composting, reuse, recycling and scare crows which are adaptive measures. Rural dwellers should also be encouraged to segregate wastes at markets, small-and medium-scale industries and social gatherings as they do so in homes. The private sector, experts, non-governmental organizations (NGOs) and individuals should be encouraged to invest in rural solid management as government cannot bear the burden alone. The pay-as-you-generate principle needs to be adopted to make rural dwellers mentally and financially committed to the maintenance of a safe and healthy environment of the study area. Environmental health officers are to ensure regular visits to households, markets, institutions (e.g. hospitals) and commercial areas to stop them from littering the environment as the consequences have risen to a crisis point.

\section{References}

Cole, C., A. Gnanapragsam, T. Cooper, and J. Singh, 2019. An Assessment of Achievements of the WEEE Directive in Promoting Movement up the Waste HIERARCHY: Experiences in the Uk. Waste Management, 87: 417-427. 
Davis, M.L., and S. J. Masten, 2004. Principles of Environmental Engineering and Sciences. McGraw Hill, New York

Gbekor, A., 2003. Domestic Waste Management. Ghana Environmental Protection Agency (EPA. Newsletter, 47 (3) Accra, Ghana.

Girling, R., 2005. Rubbish! Dirt on Our Hands and Crisis Ahead. Eder Project Books, London. Trans-World Publishers Ltd.

Igwe, P.U., 2012a. Waste Management: Environmental Injustice in the Organization of Solid Waste Management in Onitsha, Anambra State, Nigeria. Journal of Environmental Management and Safety, 3(16): 165-179.

Igwe, P.U., 2012b. Waste Management: Assessment of Heavy Metal Pollution at Agu-Awka Solid Waste Dumpsite Anambra State, Nigeria. Journal of Environmental Management and Safety, $3(6): 180-192$.

Izuagbara, C.O., and J.O. Umoh, 2005. Indigenous Waste Management Practices among the Ngwa of Southeastern Nigeria: Some Lessons and Polices Implications. Environ. Analar, 24 (2): 87-92.

Kaseva, M.E., and S.E. Mbuligwe, 2003. Appraisal of Solid Waste Collection Following Public Sector Involvement in Dar es Salaam City, Tanzania. Habitat International, 29:353-366.

Medina, M., 2002. Globalization, Development and Municipal Solid Waste Management in Third World Cities. Accessed at http: //www. gdnet. org/pdf/2002 Awards medals winners/outstanding Research Development/martin Medina Martinez paper. pdf on $10^{\text {th }} \mathrm{July}$, 2018.

Millennium Assessment Report (MAR), 2005. Living Beyond Our Means: Natural Assets and Human Well-being (Statement of the Millennium Assessment Board. Accessed at $\mathrm{http} / / / \mathrm{www}$. Millennium assessment. org/en/Reports. aspx on $10^{\text {th }} \mathrm{June}, 2018$.

National Population Commission (NPC), 2006. National Population Commission (NPC), Provisional Census Figure. Abuja Nigeria.

Ogwueleka, T.C., 2003. Analysis of Urban Solid Waste in Nsukka, Nigeria. Journal of Solid Waste Technology and Management, 29(4): 239-246.

Oluwaleye, M., 2012. Proposal for New Waste Management System in Nigeria (Lagos State. A Thesis to Faculty of Business Seinajoki University of Applied Sciences. Accessed at http://urn.fi/URN: NBN: fi: ank 2012121219226 o $16^{\text {th }}$ October, 2018.

Pitchel, J., 2005. Waste Management Practices, Municipal, Hazardous and Industrial. Taylor and Francis Group, LLC.

Prongracz, E., 2002. Re-defining the Concepts of Waste and Waste Management: Evolving the Theory of Waste Management. Dissertation to the Department of Process and Environmental Engineering, University of Oulu, Finland. Accessed at: URL:http: //herkwes. Oulu fi/ssn 03552313

Techobanglous, G., H. Theisen, and S.A. Vigil, 1993. Integrated Solid Waste Management. New Waste Technology and Management, 29(4): 239-246.

United Nations Environment Programme (UNEP), 2005. Solid Wastes Management Volume II: Regional Overviews and Information Sources ISBN 92-807-2675-5.

United Nations Habitat (UNH) ,2009. Structural Plan for Anambra State and Satellite Towns. P.O Box 30030, GPO 00100, Nairobi, Kenya. ISBN 978-92-1-132117-3 Pp. 18-19.

Unites States Development for Agriculture (USDA), 1999. Agricultural Development. Assessed at http: www.gov/wps portal/usda/usdahome on $5^{\text {th }} \mathrm{July}, 2018$.

Vlachos, E., 2000. North American Experiences with Public Participation.Colorado State University, Fort Collins Co. 80523. En Coutro Sobre Consulta Public no Proceso de Avaliacao Ambientel, 25 Maio.

World Commission on Environment and Development (WCED), 1987. Our Common Future, From One Earth to One World. Oxford University Press.

World Health Organization (WHO), 2006. Guidelines for Drinking Water Quality Incorporating First Addendum Vol. 1. Recommendations. World Health Organization. Geneva.

Yoshizawa, S.H., S. Tanaka, and A.V. Shedar, 2004. Global Trends in Waste Generation. Global Symposium on Recycling, Waste Treatment and Clean Technology (REWAS), 26-29 September, 2004, Madrid, Spain. 